\title{
Hukum Islam sebagai rekayasa sosial dan implikasinya dalam undang-undang perkawinan di Indonesia
}

\author{
Danu Aris Setiyanto \\ Penyuluh Agama Islam KUA Eromoko, Wonogiri, Jawa Tengah \\ E-mail:danuaris07@gmail.com \\ DOI: 10.18326/ijtihad.v17i2.175-189
}

\begin{abstract}
This study focuses on the role of Islamic law as social engineering and its implications in marriage law in Indonesia. Islamic law has always been a concern among legal experts and studies. One interesting thing is the effort to achieve justice through the application of Islamic law which functioned as social engineering. Though the nature of Islamic law is the dimension of social justice but at the same dimensions of the Godhead. In the Indonesian context, it is understood that the marriage law in Indonesia is the implication. As this study included the study of literature and research data analyzed by the theory of law as a social engineering with the sociological approach. The results of this study concluded Law Islamic law can function and formulated as social engineering in the form of state regulation and in fact it is contained in the articles of the Marriage Law in Indonesia.
\end{abstract}

Penelitian ini fokus terhadap peran hukum Islam sebagai rekayasa sosial dan implikasinya dalam hukum perkawinan di Indonesia. Hukum Islam selalu menjadi perhatian dan kajian dikalangan ahli hukum. Salah satu hal yang menarik adalah upaya pencapaian keadilan melalui penerapan hukum Islam yang difungsikan sebagai rekayasa sosial. Padahal hakikat dari hukum Islam adalah memiliki dimensi keadilan sosial tetapi sekaligus dimensi Ketuhanan. Dalam konteks Indonesia, dipahami bahwa hukum perkawinan di Indonesia merupakan implikasinya. Adapun penelitian ini termasuk kajian studi pustaka dan data penelitian dianalisis dengan teori hukum sebagai rekayasa sosial dengan pendekatan sosiologis. Hasil penelitian ini menyimpulkan UU hukum Islam dapat berfungsi dan diformulasikan sebagai rekayasa sosial dalam bentuk regulasi negara dan secara fakta hal tersebut terdapat dalam pasal-pasal UU Perkawinan di Indonesia.

Keywords: Islamic law; social engineering; Marriage Law in Indonesia. 
ljtihad: Jurnal Wacana Hukum Islam dan Kemanusiaan, Volume 17, No. 2, Desember 2017: 175-189

\section{Pendahuluan}

Beberapa wilayah dengan masyarakat muslim saat ini, memang seakan memiliki rasa gelisah. Hal ini karena banyak negara yang mayoritas muslim tidak untuk merealisasikan beberapa aspek hukum Islam yang selalu mempengaruhi sistem hukum pada masyarakat, yang sematamata bukan hanya pada bidang hukum privat dan hukum keluarga semata. Secara fakta, banyak masyarakat muslim mengadopsi undang-undang hukum dan institusi dari negaranegara Eropa sekitar akhir abad kesembilan belas dan awal abad ke dua puluh. Walaupun demikian, ternyata mereka tidak mengadopsi secara penuh catatan hukum Islam dalam sistem hukum di masyarakat yang mayoritas muslim (Ergene, 2013: 1041-1042).

Hukum Islam memang sudah lama menjadi perhatian ilmiah dalam bidang hukum. Sebelum Indonesia merdeka, kajian hukum keluarga Islam selalu menjadi perbandingan dengan hukum yang lain. Hal itu bukan saja dari kalangan muslim, namun juga orang nonIslam. Bahkan, perhatian Pemerintah Belanda selama masa penjajahan telah menghasilkan beberapa teori hukum yang masih dikaji hingga saat ini (Anshori, 2010: viii).

Tidak berbeda dengan kajian hukum yang lain, kajian hukum Islam juga tidak terlepas dengan perubahan sosial. Hukum Islam memang salah satu bagian dari kajian hukum yang juga tidak terlepas dari pendekatan sosial. Lebih dari itu, pendekatan sosial bisa dikatakan sebagai salah satu metode untuk memahami agama itu sendiri (Ishak, 2013: 71).

Perkembangan hukum Islam sendiri selalu tak lepas dari unsur masih terbukanya pintu ijtihad dalam Islam sendiri. Hal ini karena hukum Islam selalu bisa beriringan antara kebenaran ortodoks dan keluwesan dalam berbagai perspektif. Islam merupakan merupakan agama wahtu dan juga sebagai agama rahmatan lil alamin yang harus beradaptasi dengan keadaan sosial masyarakat.

Sebagaimana hukum yang lain, maka hukum Islam juga berfungsi sebagai rekayasa sosial. Namun, untuk mengatakan seperti ini bukanlah hal yang mudah. Hal ini disebabkan karena hukum Islam tidak terlepas dari adanya keterpaduan tujuan syariat dari wahyu dan aplikasi dalam kehidupan manusia. Dalam hukum Islam pola tingkah laku manusia sekaligus ada otoritas kehendak Allah yang tertinggi yang tidak bisa ditarik jelas perbedaannya (Anshori, 2005:66).

Bagian dari hukum Islam adalah hukum perkawinan di Indonesia. Sejarah panjang pembentukkannya yang sangat sengit antara kaum sekuler dan kaum religius Islam saat itu 
menghasilkan sebuah revolusi aturan perkawinan di Indonesia. Sedangkan, untuk mengetahui sejauh mana peran implikasinya dan bagaimana fungsi hukum tersebut sebagai rekayasa sosial merupakan hal yang menarik untuk dibahas dalam penelitian ini.

Dengan penjelasan di atas, maka dapat dirumuskan masalah, yaitu: 1) Bagaimana fungsi hukum Islam sebagai rekaya sosial?; 2) apa implikasi fungsi hukum Islam sebagai rekaya sosial dalam UU No. 1 Tahun 1974 tentang Perkawinan (selanjutnya disebut UU Perkawinan) di Indonesia?

\section{Pengertian hukum}

Untuk memahami makna hukum dan rekaya sosial, maka diperlukan konsep yang lebih umum, yaitu pengertian hukum itu sendiri. Pada hakikatnya definisi hukum sangat banyak. Para akademisi sudah banyak mendefinisikan hukum dengan berbagai sudut pandang. Definisi hukum setidaknya memiliki tiga pola, yaitu dari kaum antropolog, kaum para juris atau ahli hukum dominan, dan dari sosiolog (Indonesia, 2013: 239) . Berbagai pandangan makna hukum ini kemudian berimplikasi adanya berbagai pendekatan dan teori tentang hukum.

Dalam buku “Antropologi Hukum: Sebuah Bunga Rampai sebagaimana dikutip oleh Listya Binawan, kaum antropolog mengartikan hukum sebagai aturan yang lebih luas termasuk aturan dalam kampung. Hukum menurut kaum antropolog berfungsi bagi manusia dan masyarakat dan bertujuan untuk menjamin keadilan (Indonesia, 2013: 239-240). Sedangkan bagi ahli hukum dominan mengartikan hukum dalam arti yang sempit, yang hanya terkait dengan aspek normatif semata. Penekanan makna hukum dalam hal ini adalah adanya unsur kepastian hukum dan biasanya tidak akan jauh dari positivisme hukum (Indonesia, 2013: 240). Pengertian ini sebagaimana yang disampaikan oleh Kansil dalam bukunya "Pengantar Ilmu Hukum dan Tata Hukum Indonesia". Pengertian hukum memiliki beberapa unsur, yaitu peraturan tingkah laku manusia dalam pergaulan masyarakat, peraturan yang diadakan oleh badan resmi, peraturan yang bersifat memaksa, dan sanksi (Kansil, 1989: 39).

Unsur-unsur dari hukum tersebut memiliki kesamaan dengan pengertian hukum yang disampaikan oleh ahli hukum Belanda J. Van Kan. Menurutnya, hukum adalah keseluruhan ketentuan-ketentuan kehidupan yang bersifat memaksa, dan melindungi kepentingankepentingan dalam masyarakat. Pendapat yang mirip dengan ini beberapa pendapat ahli 
ljtihad: Jurnal Wacana Hukum Islam dan Kemanusiaan, Volume 17, No. 2, Desember 2017: 175-189

hukum lain, seperti Rudolf van Jhering, Wiryono Projodikoro dan O. Notohamidjojo (Anshori, 2005: 33).

Sedangkan para sosiolog mengartikan hukum sebagai sesuatu yang dinamis. Hukum dipandang bukan hanya berfungsi sebagai kepastian, ketertiban, melainkan hukum juga bermanfaat yang lebih luas dalam ruang dan waktu., yaitu bertujuan untuk mendidik masyarakat (Indonesia, 2012: 240). Hukum secara sosiologis merupakan lembaga kemasyarakatan (social Institution) yang merupakan himpunan nilai-nilai, kaidah-kaidah, dan pola-pola perilakuan yang berkisar pada kebutuhan kebutuhan pokok manusia. Dalam hal ini, hukum dipandang berdampingan dengan lembaga kemasyarakatan lainnya, dan saling mempengaruhi antara satu dan lainnya (Soekanto, 2013: 4).

Dalam sosiologi hukum diartikan sebagai nilai-nilai yang ada dalam hukum itu sendiri, dan pengalaman-pengalaman hukum. Hukum dipadang dari sisi apa yang benar-benar nampak dan terjadi. Sehingga dalam sosiologi hukum disebutkan bahwa hukum merupakan hukum yang ditafsirkan dari bentuk perilaku dan dimanifestasikan bahan hukum sesuai makna dalam hukum (Gurvitch, 1947: 41-42).

\section{Teori hukum sebagai rekayasa sosial (social engineering)}

Pemikiran hukum sebagai rekayasa sosial muncul dari Roscou Pound dan kemudian diterima oleh sebagian ahli hukum termasuk di Indonesia. Istilah rekayasa sosial dapat dipahami bahwa istilah yang sengaja lebih mementingkan negara daripada kepentingan individu (Indonesia, 2012: 239). Di Indonesia, pemikiran hukum ini pertama kali diadopsi oleh Mochtar Kusumaadja dan disebut sebagai teori hukum pembangunan. Selanjutnya pemikiran ini juga dianut oleh Satjipto Rahardjo.

Roscou Pound berpendapat bahwa hukum harus dikembangkan berdasarkan filosofi kegunaannya. Dia beragumen bahwa hukum harus mampu memenuhi kebutuhan kebutuhan sosial di abad modern. Sehingga dia mengatakan bahwa "law in action, not law in the books". Dalam memandang bahwa hukum sebagai instrumen rekayasa sosial (social engineering) untuk mengamankan adanya perubahan sosial (Gray, 1999: 672).

Kontruksi hukum sebagai rekayasa sosial (social engineering) merupakan bentuk pemahaman bahwa hukum merupakan bagian dari perubahan sosial. Perubahan sosial sering disebut 
sebagai dinamika masyarakat atau transformasi sosial memang merupakan hal yang bersifat pasti. Sehingga dapat diketahui bahwa hukum mempunyai hubungan yang kuat dengan realitas sosial dan harus memiliki hubungan simbiosis antara keduanya (Ishak, 2013: 72).

Dalam buku Lawrence Stone yang berjudul Road to Divorce sebagaimana dikutip oleh Ron Shaham dijelaskan bahwa hubungan hukum dengan publik atau masyarakat sebenarnya sederhana. Menurutnya, hukum bisa dipengaruhi oleh masyarakat, atau pada sisi lain hukum yang mempengaruhi masyarakat. Pertama, hukum dipengaruhi masyarakat salah satunya ditunjukkan dengan adanya para legislator yang membuat hukum sendiri pasti dipengaruhi oleh nilai-nilai dari masa dimana hokum itu dibuat (Shaham, 1995: 258). Kedua, di sisi lain sangat berbeda dengan apa yang seharusnya, undang-undang itu sendiri adalah bentukan opini publik dan perilaku masyarakat. Keberadaan hukum terjadi melalui dua cara, yaitu berangkat dari masyarakat kemudian diartikan oleh para pengacara dan hakim, atau hakim dan pengacara memberikan interpretasi hukum tersebut dan menerapkannya dalam masyarakat. Sehingga dengan demikian sangatlah jelas bahwa terdapat hubungan timbal balik antara hukum yang telah ditetapkan, teori-teori keadilan, dan latar belakang kondisi sosial, ekonomi, dan budaya (Shaham, 1995: 258).

Berdasarkan penjelasan di atas diketahu bahwa hukum bisa dimaknai sedehana, yaitu bottom to up (dari realita sosial masyarakat menjadi hukum negara) atau up to bottom (dari hukum kepada realita masyarakat). Sehingga dapat diketahui, kedudukan hukum sebagai rekayasa sosial terletak pada jenis yang kedua, yaitu hukumlah yang mengatur masyarakat. Jika hukum dari instansi lembaga hukum negara, maka kepentingan negara itulah yang mengatur terjadi apa yang ada dalam masyarakat.

Hukum sebagai rekayasa sosial merupakan fenomena yang muncul pada abad ke-20. Penekanan makna rekayasa sosial dalam hal ini adalah bahwa hukum adalah badan-badan dari kaidah sosial yang sudah tertanam dalam diri masyarakat, yang sudah menjadi syarat dengan keputusan politik. Sehingga hukum menjadi sarana bentuk implementasi politik yang telah kehilangan akarnya dari kehidupan yang tradisional. Sehingga hukum kemudian tidak melihat masa lampau, namun hukum kemudian melihat ke depan dengan melihat masa depan yang dicita-citakan. Dengan demikian, hukum tidak lagi mempertahankan status quo, namun kemudian hukum melakukan perubahan sosial (Rosana: 2013, 109). 
Hukum sebagai rekayasa sosial (social engineering) merupakan upaya dalam menghadapi permasalahan hukum yang terjadi dimana hukum-hukum tertentu yang dibentuk dan diterapkan tidak dapat berfungsi dengan baik. Hal ini biasanya adanya beberapa halangan yang ada. Adapun gejala dalam halangan bidang hukum dapat timbul dari pembentuk hukum, penegak hukum, pencari keadilan, maupun golongan lain dalam masyarakat. Dengan demikian, hukum merupakan sarana rekayasa sosial yang ditunjukan untuk mengubah perikelakuan warga masyarakat, sesuai dengan tujuan-tujuan hukum yang telah ditetapkan (Soekanto, 2013: 135).

\section{Hukum Islam sebagai rekayasa sosial masyarakat muslim}

Islam merupakan agama yang terdiri dari komponen penting, yakni, iman, hukum, dan akhlak (Anshori, 2005: 58). Agama Islam juga selalu berhubungan erat dengan ruang dan waktu sehingga diperlukan ijitihad terhadap segala permasalahan yang terjadi dimasyarakat. Walaupun demikian, Islam tetap menjaga bahwa segala interpresi tidak bertentangan dengan tujuan syara'. Prinsip inilah kemudian berkembang dalam beberapa bidang Islam, terutama hukum atau fikih.

Hukum Islam merupakan bagian yang penting dalam pembahasan hukum pada umumnya. Hukum keluarga Islam sendiri juga tidak terlepas dari pengaruh-pengaruh pendekatan sosial. Padahal hukum Islam merupakan hukum yang menarik dikalangan ahli hukum karena selalu menjadi perdebatan dalam berbagai sisi terutama tentang metodologi unifikasi, dan pembahasan pembaharuan hukumnya.

Apabila ditelaah lebih lanjut, pada dasarnya hukum Islam bisa dimaknai dalam dua sisi. Pada satu sisi hukum Islam bermakna sebagai ilmu, dan pada sisi lain sebagai produk ilmu. Sebagai produk ilmu, hukum Islam sendiri ada empat macam produk pemikiran hukum Islam, yaitu kitab-kitab fikih, fatwa ulama, keputusan pengadilan dan peraturan perundang-undangan (Yusdani, 2015: 1). Sementara hukum Islam dimaknai sebagai ilmu pengetahuan disebabkan karena adanya karakteristik keilmuan bahwa dari hukum Islam dihasilkan akumulasi pengetahuanpengetahuan yang tersusun melalui asas-asas tertentu, pengetahuan-pengetahuan itu terjaring dalam suatu kesatuan sistem, dan mempunyai metode-metode tertentu (Yusdani, 2015: 4).

Untuk mempertemukan dan mendialogkan antara hukum Islam dan rekayasa sosial memang bukanlah hal yang mudah. Hal ini disebabkan karena Islam memandang bahwa 
hukum memiliki arti yang lebih luas daripada arti hukum pada umumnya. Dalam hukum Islam ada sistem keseimbangan yang terkait erat, yaitu hukum yang mangatur seluruh gerak dan tata tertib benda mati dan benda hidup yang disebut sebagai natural law, dan tata tertib hukum SWT ((sunatullah) yang wajib diyakini kebenarannya (Anshori, 2005: 61-62).

Dalam memahami permasalahan di atas, maka pada dasarnya terdapat dua teori besar di dalam pemikiran hukum Islam, yang memiliki paradigma dan cara pandang yang bukan saja berbeda, akan tetapi juga saling bertentangan. Dua teori tersebut adalah sebagai teori keabadian dan teori adaptabilitas. Teori adaptabilitas sering disebut sebagai toeri normativitas hukum Islam. Teori ini mengukuhkan bahwa hukum Islam adalah wahyu dari Tuhan yang tidak bisa berubah dan tidak dapat beradaptasi dengan perkembangan zaman (Suherman, 2010: 112).

Sementara pada teori yang kedua hukum Islam dipahami sebagai hukum yang diciptakan Tuhan untuk kepentingan umat manusia dan bisa beradaptasi dengan perkembangan zaman dan perubahan tempat. Hal ini demi mewujudkan kemaslahatan umat manusia (Suherman, 2010: 112). Hukum Islam yang bersumber kepada al-Quran dan sunnah merupakan aturan yang timbul dari Allah yang bertujuan untuk mengatur seluruh aspek kehidupan manusia, namun tentu saja keduanya memilki aspek yang sangat terbatas. Kompleksitas permasalahan hukum di abad modern tentu saja tentu saja tidak dapat terekam semuanya dalam keduanya. Sehingga hemat kata, peluang ijtihad dalam hukum Islam tidaklah berhenti (Azhari, 2016: 198).

Dengan penjelasan di atas, hukum Islam memiliki ruang yang bersingungan dengan sosial masyarakat. Sehingga hukum Islam diakui memiliki sifat yang elastis dan fleksibel dalam beradaptasi dengan perubahan sosial. Keberadaanya yang demikian, menjadikan hukum Islam menjadi dinamis dan relevan sesuai dengan perkembangan zaman, keadaan, dan tempat (Azhari, 2016: 201).

Salah satu metode untuk mempertemukan antara hukum Islam dan rekayasa sosial dapat melalui kombinasi tujuan hukum itu sendiri, yaitu mencapai keadilan. Keadilan merupakan tujuan hukum baik itu dari hukum Islam maupun hukum umumnya. Namun dalam hal ini terdapat dua hal penting yang perlu diperhatikan, yaitu sumber dan formulasi keadilan itu sendiri.

Apabila dilihat dari sumber hukum Islam berasal dari wahyu Tuhan, sementara hukum pada umumnya berasal dari manusia itu sendiri atau lingkungan sosial manusia itu sendiri. 
Sehingga ada tantangan bahwa hukum Islam yang pada dasarnya berasal dari wahyu ini harus mampu mengaplikasikan makna keadilan itu sesuai dengan pandangan manusia di segi lain. Selain itu, untuk mencapai keadilan maka hukum Islam harus mampu diformulasikan menjadi produk hukum atau panduan dalam mencari keadilan. Formulasi hukum Islam ini bertujuan untuk mencapai sebuah hukum yang universal dengan mencapai keadilan terahadap manusia dan keadilan di sisi Tuhan (Anshori, 2005: 63-64).

Dalam pencarian mencari bentuk formulasi untuk mencari keadilan itulah maka kemudian hukum Islam kemudian harus berhadapan dengan berbagai permasalahan sosial lainnya. Yang tentu saja terkait bisa terkait dengan budaya, politik, ideologi bangsa, dan sebagainya. Lebih dari itu, hukum Islam juga harus mampu merespon dan mengaplikasikan dalam regulasi negara yang bersentuhan dengan isu hak asasi manusia dan gender.

Hukum Islam sebagai bagian dari prooduk pemikiran ulama klasik dalam konteks rekayasa sosial dipahami bukanlah hal yang absolut atau tidak menerima perubahan. Sehingga hal yang tidak lagi sesuai dengan masa kontemporer diperlukan tinjaun kembali (Azhari, 2016: 199). Dalam mendudukan fungsi hukum Islam dalam menghadapi perubahan sosial, maka diperlukanlah ilmu-ilmu lain yang terkait dan salah satunya adalah ilmu sosial supaya kekakuan dan formalisme hukum Islam dapat teruraikan.

Dalam konteks sebuah negara, dari empat produk hukum Islam yang ada, maka yang paling efektif adalah produk hukum Islam yang menjadi peraturan perundang-undang. Hal ini karena bentuk ini mampu memberikan efek memaksa dan menjadi sebuah rekayasa sosial dalam masyarakat itu sendiri. Penjelasan ini dalam konteks Indonesia menjadi pembasan pada subab berikutnya.

Berdasarkan penjelasan di atas, hukum Islam sebagai rekayasa sosial merupakan upaya kembali dalam menengakan keadilan dengan cara mengaplikasikan hukum Islam dalam bentuk regulasi atau perundang-undagan dalam negara. Selain itu, hukum Islam harus mampu beradaptasi dengan terus melakukan berbagai pendekatan dengan ilmu-ilmu lain sehingga menghasilkan refleksi sosial.Posisi yang demikian, menjadikan hukum Islam menjadi lebih mudah dalam pembentukan masyarakat yang diharapkan sebagai upaya memperoleh keadilann melalui rekayasa sosial. 
Hukum Islam sebagai rekayasa sosial dan implikasinya... (Danu Aris Setiyanto)

\section{Aspek sejarah sosial dan tanggapan terhadap hukum perkawinan Indonesia sebagai rekayasa sosial hukum Islam}

Hukum perkawinan di Indonesia selalu terkait erat dengan hukum Islam. Sedangkan periodesasi sejarah hukum perkawinan Indonesia dibagi menjadi tiga tahapan, yaitu pada masa pra penjajahan, masa penjajahan, dan pasca kemerdekaan (Hidayat, 2014: 3-14). Secara umum pada masa pra sejarah, hukum perkawinan di Indonesia sudah menerapkan hukum keluarga Islam. Pada saat ini permaslaahan hukum perkawinan diselesaikan melalui mufti dan qadhi di wilayah kerajaan (Hidayat, 2014: 1).

Setiap periode ini hukum Islam mengalami pasang surut terutama pada masa penjajahan.Pada masa awal kedatangan VOC, Hukum Islam memiliki ruang dan tempat untuk dijalankan. Mereka mengakui bahwa hukum Islam sangat diakui keberadaanya di masyarakat Indonesia (Hidayat, 2014: 6-9). Namun pada akhirnya terus terjadi dinamisasi, sehingga pelaksaan hukum Islam kemudian menjadi dibatasi dan digantikan dengan hukum adat. Kemudian sering disebut adanya teori receptio in complexu dan teori receptie. Kedua toeri sangat populer di antara para pengkaji hukum Islam, dan efek serta respon dari pertentangan hukum ini masih ada hingga saat ini (Anshori, 2010: viii).

Sedangkan pada masa penyusunan UU Perkawinan setelah Indonesia merdeka, dilatarbelakangi adanya keinginan untuk memiliki hukum perkawinan yang sesuai dengan ciri khas bangsa Indonesia sendiri. Proses pembentukan UU Perkawinan bisa dikatakan sangat lama dan penuh pertentangan antara anggota DPR, pemerintah, ulama, masyarakat, dan mahasiswa. Hal ini dipicu karena adanya draf UU perkawinan yang bersifat sekuler sementara keinginan para ulama dan masyarakat UU Perkawinan disusun sesui dengan prinsipprinsip agama Islam atau sesuai fikih. Pertentangan ini akhirnya berakhir dengan ketentuan UU Perkawinan di Indonesia sesuai dengan prinsip ajaran Islam (Setiyanto: 2016: 20-21).

Dari penjelasan di atas, sebenarnya ada beberapa hal yang sudah mengambarkan sebuah rekayasa sosial dalam hukum perkawinan di Indonesia. Jika diperhatikan maka yang menjadi perhatian penting adalah adanya kepentingan politik, baik sebelum dan sesudah kemerdekaan. Pada masa penjajahan, keberadaan hukum perkawinan yang merugikan pihak Belanda kemudian direkayasa sosial sehingga hukum Islam diperkedili dan diganti dengan hukum adat. 
ljtihad: Jurnal Wacana Hukum Islam dan Kemanusiaan, Volume 17, No. 2, Desember 2017: 175-189

Sementara dalam pembentukan UU perkawinan setelah kemerdekaan terdapat sebuah keinginan yang kuat dari negara membentuk keluarga Indonesia yang berkepribadian nasional dan berwawasan modern. Selain itu, dengan adanya UU Perkawinan diharapkan dapat mengatur pembentukkan keluarga Indonesia masa depan yang cocok dengan masyarakat modern industrial. Keinginan ini disampaikan oleh Soeharto pada 16 Agustus 1973 yang menjabat presiden saat itu (Setiyanto: 2016: 1).

Dengan demikian, maka sangat jelas bahwa dalam hukum perkawinan di Indonesia adalah wujud upaya negara mengatur masyarakat (social engineering). Apabila negara merupakan kekuasaan tertinggi (to $p$ ) sebagai perencana rekayasa sosial keluarga dan masyarakat sebagai unit kecil negara (bottom), maka hubungan ini sangat menggambarkan hukum Islam dalam UU Perkawinan tersebut menjadi alat rekayasa sosial. Sehingga tujuan dari UU Perkawinan lebih mudah dicapai.

\section{Pro-kontra substansi legislasi hukum perkawinan Indonesia sebagai rekayasa sosial hukum Islam}

Rancangan UU Perkawinan memang penuh kontroversi karena memang saat terkait erat dengan agama, sosial, dan keluarga di Indonesia yang akan datang. Secara sederhana ada dua kubu yang berlawanan dalam RUU perkawinan, yaitu adanya penentang sekuler dan pendukung perkawinan secara sekuler. Pendukung sekuler lebih didominasi dari unsur lembaga negara, dan unsur pelawan sekuler datang dari masyarakat muslim, ulama, dan mahasiswa.

Untuk mengetahui sejauh mana pro-kontra legislasi perkawinan sebagai salah satu bentuk rekayasa sosial dalam hukum Islam, maka dapat dilihat dari beberapa materi dalam rancangan UU perkawianan. Selanjutnya dapat dibandingkan dengan kitab-kitab fikih atau dengan yang ada dalam pengesahan UU perkawinan dan adanya respon dari MK yang memutuskan yudicial review beberapa pasal UU Perkawinan.

Beberapa rancangan pasal yang mendapatkan pro-kontra dalam legislasi, yaitu 1) aturan pencatatan perkawinan sebagai syarat sahya perkawinan; 2) poligami harus mendapatkan izin dari pengadilan; 3) pembatasan usia minimal perkawinan; 4) perkawinan beda agama; 5) pertunangan; 6) perceraian harus dengan izin pengadilan; 7) pengangkatan anak (Hermawati, 2015: 38-39). Point-point di atas dianggap bertetangan dengan ajaran Islam 
dan tidak sesuai dengan situasi Indonesia. Sehingga hemat kata, jika rancangan saat itu disahkan begitu saja akan ada kekhawatiran yang muncul, yaitu adanya masyrakat yang tidak sesuai dengan ajaran Islam atau dalam kata lain hukum Islam tidak mampu bersaing untuk menciptakan rekayasa sosial sejak awal legislasi.

Sebelum jauh berbicaraa tentang rincian materi dalam UU perkawinan, maka perlu disampaikan bahwa hukum Islam sangatlah dapat diterima oleh masyarakat dalam berbagai bentuknya. Hal ini juga didorong adanya suara mayoritas muslim di Indonesia yang menjadi kekuatan suara dalam proses legislasi.

Dalam pembahasan ini, tidak akan dibahas secara rinci semua materi yang ada dalam UU Perkawinan. Namun, dalam tulisan ini akan disoroti 2 pasal krusial yang berhubungan dan dengan pokok pembahasan, yaitu Pasal 2 ayat (2) dan Pasal 43 ayat (1) UU Perkawinan. Di bawah ini adalah perbandingan dari rancangan UU versi pemerintah yang mewakili negara, sedangakan RUU Perkawinan yang mewakili umat Islam dan masyarakat, serta UU Perkawinan dan putusan MK.

Tabel 1. Perbandingan RUU dan UU Perkawinan (Alimudin, tth: 7-8).

\begin{tabular}{|c|c|c|c|}
\hline $\begin{array}{l}\text { RUU Perkawinan } \\
\text { Versi Pemerintah }\end{array}$ & $\begin{array}{c}\text { RUU Perkawinan } \\
\text { Versi Ulama }\end{array}$ & UU Perkawinan & Putusan MK \\
\hline $\begin{array}{l}\text { Pasal } 2 \text { ayat (1) } \\
\text { perkawinan adalah } \\
\text { syah apabila dilakukan } \\
\text { dihadapan pegawai } \\
\text { pencalal perkawinan } \\
\text { dalam daftar pcncatat } \\
\text { perkawinan oleh } \\
\text { pegawai tersebut, dan } \\
\text { dilangsungkan } \\
\text { menunut ketentuan } \\
\text { undang-undang ini } \\
\text { dan atau ketentuan } \\
\text { hukum perkawinan } \\
\text { pihak-pihak yang } \\
\text { melakukan } \\
\text { perkawinan, sepanjang } \\
\text { tidak bcrtcntangan } \\
\text { dengan undang- } \\
\text { undangrini. }\end{array}$ & $\begin{array}{l}\text { Pasal } 2 \text { ayat (1) } \\
\text { perkawinan adalah } \\
\text { syah apabila dilakukan } \\
\text { dihadapan pegawai } \\
\text { pencatal perkawinan, } \\
\text { dicatatkan dalam } \\
\text { daftar pencatat } \\
\text { perkawinan oleh } \\
\text { pegawai tersebut, dan } \\
\text { dilangsungkan } \\
\text { mcnurut kctcntuan } \\
\text { undang-undangini } \\
\text { dan atau ketentuan } \\
\text { hukum perkawinan } \\
\text { pihak-pihak yang } \\
\text { melakukan } \\
\text { pcrkawinan. }\end{array}$ & $\begin{array}{l}\text { Pasal } 2 \\
\text { (1). Perkawinan } \\
\text { adalah sah, apabila } \\
\text { dilakukan menurut } \\
\text { hukum masing- } \\
\text { masing agamanya } \\
\text { dan kepercayaannya } \\
\text { itu. } \\
\text { (2) Tiap-tiap } \\
\text { perkawinan dicatat } \\
\text { mcnurut peraturan } \\
\text { perundang- } \\
\text { undangan yang } \\
\text { berlaku. }\end{array}$ & $\begin{array}{l}\text { Tetap seperti semula. } \\
\text { Pasal ini tidak } \\
\text { dibatalkan olch MK. }\end{array}$ \\
\hline
\end{tabular}


ljtihad: Jurnal Wacana Hukum Islam dan Kemanusiaan, Volume 17, No. 2, Desember 2017: 175-189

\begin{tabular}{|c|c|c|c|}
\hline $\begin{array}{l}\text { RUUU Perkawinan } \\
\text { Versi Pemerintah } \\
\end{array}$ & $\begin{array}{c}\text { RUJU Perkawinan } \\
\text { Versi Ulama } \\
\end{array}$ & UU Perkawinan & Putusan MK \\
\hline $\begin{array}{l}\text { Pasal } 49 \text { UUP: "Anak } \\
\text { yg dilahirkan di luar } \\
\text { perkawinan hanya } \\
\text { mempunyai huluunganl } \\
\text { perdata dengan ibunya } \\
\text { dan keluarga ibunya." } \\
\text { Ayat (2): "Anak yang } \\
\text { dimaksud dalam ayat } \\
\text { (1) pasal ini, dapat } \\
\text { diakui olch ayahnya". } \\
\text { Ayat (3): "Anak yang } \\
\text { dinnaksud dalann ayat } \\
\text { (2) pasal ini, dapat } \\
\text { disyahkan dengan } \\
\text { pcrkawinan }\end{array}$ & $\begin{array}{l}\text { Pasal } 49 \text { UUP: "Anak } \\
\text { yg dilahirkan di luar } \\
\text { perkawinan hanya } \\
\text { mempunyai hubungarl } \\
\text { perdata dengan } \\
\text { ibunya dan keluarga } \\
\text { ibunya." }\end{array}$ & $\begin{array}{l}\text { Pasal 49, ayat (1) } \\
\text { Anak yg dilahirkan } \\
\text { di luar pertawinan } \\
\text { haniya mnempunyai } \\
\text { hubungan perdata } \\
\text { dengan ibunya dan } \\
\text { kcluarga ibunya (2) } \\
\text { Anak yg dilahirkan } \\
\text { di luar perkawinan } \\
\text { hanya mempunyai } \\
\text { hubungan perdata } \\
\text { dengann ibunya danı } \\
\text { keluarga ibunya } \\
\text { (2) }\end{array}$ & $\begin{array}{l}\text { MK mcml atalkan } \\
\text { Pasal } 43 \text { ayat (1) } \\
\text { UUP, sehingga } \\
\text { menjadi: "Anlak yang } \\
\text { dilahirka ndi luar } \\
\text { perlkawinan } \\
\text { mompunyai } \\
\text { hubungan perdata } \\
\text { dengan ibunya dan } \\
\text { kcluarga ilunya scrta } \\
\text { dengan laki laki } \\
\text { sebagai ayahnnya yang } \\
\text { dibuktikan } \\
\text { berdasarkan ilmu } \\
\text { pcngctahuan dan } \\
\text { teknologi dan/atau } \\
\text { alat bukti lain } \\
\text { monurut hukum } \\
\text { mempunyai } \\
\text { hubungan darah, } \\
\text { termasuk hubungan } \\
\text { perdata dengan } \\
\text { kcluarga ayahnya." }\end{array}$ \\
\hline
\end{tabular}

Dari tabel di atas dapat dianalisa bahwa tarik menarik antara kepentingan agama dan negara sangatlah ada. Pada data yang disampaikan pemerintah memang ada beberapa yang lebih sekuler dalam hal hak perdata anak, sementara ulama lebih menegaskan pentingnya nilai-nilai agama dalam perwujudan keluarga nasional kedepan. Namun pada akhirnya kemudian pemerintah menerima saran dari ulama sebagai UU Perkawinan (Hermawati, 2015: 39) dan sebagai bentuk rekayasa sosial keluarga Indonesia.

Pada sisi lain, adanya perdebatan dalam rancangan materi UU Perkawinan memberikan ilustrasi adanya keingainan kuat untuk menghilangkan konsep-konsep bekas hukum Belanda yang telah mengakar dan telah mengibiri hukum Islam di Indonesia (Hermawati, 2015: 43). Sehingga diharapkan sebuah negara mampu menciptakan kondisi sosial melalui hukum perkawinan yang sesuai dengan jatidiri dan agama Islam di Indonesia.

Sedangkan adanya upaya amandemen UU Perkawinan di Indonesia lebih bisa dimaknai sebagai bentuk menguatnya gejala fundamentalisme agama di Indonesia(Hermawati, 2015: 
43). Perspektif yang dibangun adalah keinginan mengantarkan syariat Islam menjadi hukum publik yang diterima oleh semua kalangan, yang kompatibel dengan kehidupan demokrasi modern (Hermawati, 2015: 41). Lebih mudahya bisa dikatakan bahwa "agama menyatu bersama negara", namun harus bisa disesuikan dengan kebutuhan sosial yang berkembang.

Apabila diamati lebih mendalam maka materi UU Perkawinan di Indonesia tidak semua sama dengan kitab-kitab fikih. Misalnya saja masalah pencatatan perkawinan dalam Pasal 2 ayat (2) UU Perkawinan yang menyatakan bahwa tiap-tiap perkawinan dicatat menurut peraturan perundang-undangan yang berlaku. Secara umum, ulama di Indonesia menyetujui persyaratan ini bahkan tidak ada aksi yang terbuka yang menentang untuk hal ini. Begitu pula juga masalah percerai yang harus di depan pengadilan dalam Pasal 39 ayat (1) UU perkawinan, dan permasalahan poligami dalam Pasal 3 ayat (1) dan (2) tentang poligami.

Jika diperhatikan fungsi hukum sebagai rekayasa sosial dalam UU Perkawinan terkait dengan pencatat perkawinan bisa terlihat dari penjelasan UU Perkawinan pada bagian asas atau prinsip perkawinan di Indonesia.

"Pencatatan tiap-tiap perkawinan adalah sama halnya dengan peristiwaperistiwa penting dalam kehidupan seseorang, misalnya kelahiran, kematian yang dinyatakan dalam Suratsurat keterangan, suatu akte resmi yang juga dimuat dalam pencatatan."

Hal ini tentu saja menjadi sebuah bentuk kekuasan negara dalam merekayasa sosial dalam bentuk menambah persyaratan perkawinan di luar yang disebutkan kitan fikih. Negara mencatat perkawinan merupakan sebagai bentuk bukti perlindungan kepada seluruh warga negaranya dalam menjamin hak dan kewajiban dalam setiap anggota keluarga. Dalam hal yang demikian, maka dapat diketahui bahwa sesungguhnya terdapat implimentasi hukum Islam dalam konteks nasional.

Berdasarkan penjelasan di atas, maka dapat dikatakan bahwa hukum perkawinan merupakan bentuk positivisasi hukum Islam dalam hukum nasional di Indonesia. Bahkan secara hemat kata, dalam UU perkawinan orientasi hukum Islam berupaya memperjuangkan implementasi ajaran secara komprehensif, baik aqidah, syariah, maupun etika moral (Fitriyani, 2013: 457). Dengan kata lain, pada hakikatnya, hukum Islam dapat diterima oleh masyarakat muslim dalam hukum nasional. 
ljtihad: Jurnal Wacana Hukum Islam dan Kemanusiaan, Volume 17, No. 2, Desember 2017: 175-189

\section{Penutup}

Hukum Islam sebagai rekayasa sosial merupakan upaya kembali dalam menengakkan keadilan dengan cara mengaplikasikan hukum Islam dalam bentuk regulasi atau perundang-undangan dalam negara. Selain itu, hukum Islam harus mampu beradaptasi dengan terus melakukan berbagai pendekatan dengan ilmu-ilmu lain sehingga menghasilkan refleksi sosial. Posisi yang demikian, menjadikan hukum Islam menjadi lebih mudah dalam pembentukan masyarakat yang diharapkan sebagai upaya memperoleh keadilan melalui rekayasa sosial.

Implikasi hukum Islam dalam UU Perkawinan, bisa dilihat dari sejarah legislasi dan materi UU Perkawinan di Indonesia. Dalam aspek sejarah, pembentukan UU perkawinan setelah kemerdekaan terdapat sebuah keinginan yang kuat dari negara membentuk keluarga Indonesia yang berkepribadian nasional dan berwawasan modern. Selain itu, dengan adanya UU Perkawinan diharapkan dapat mengatur pembentukkan keluarga Indonesia masa depan yang cocok dengan masyarakat modern industrial. Keinginan ini disampaikan oleh Soeharto pada 16 Agustus 1973. Dalam proses legislasi, para ulama dan mahasiswa sangat menentang rancangan UU Perkawinan yang dianggap sekuler. Sehingga akhirnya hukum Islam mampu diterima dalam UU Perkawinan.

Bentuk penerimaan hukum Islam dalam UU Perkawinan dapat diamati dari beberapa pasal yang ada. Hukum perkawinan merupakan bentuk positivisasi hukum Islam dalam hukum nasional di Indonesia. Bahkan secara hemat kata, dalam UU perkawinan orientasi hukum Islam berupaya memperjuangkan implementasi ajaran Islam secara komprehensif, baik aqidah, syariah, maupun etika moral.

\section{Daftar pustaka}

Anshori, Abdul Ghofur. Filsafat Hukum, Sejarah, Aliran dan Pemaknaan. Yogyakarta: Gadjah Mada University Press, 2005.

. Filsafat Hukum Kewarisan Islam Konsep Kewarisan Bilateral Hazairin. Yogyakarta: UII Press, 2010.

Azhari, Fathurrahman. "Dinamika Perubahan Sosial dan Hukum Islam”, dalam At-Tahrir Vol. 16, No. 1 (Mei 2016): 198-207.

Ergene, Bogac A. " Islamic Law in Action: A Historical Discussion" dalam Law and Social Inquiry Vol. 38, No. 4, (2013): pp. 1041-1042. 
Fitriyani, Ab Basir Laupe. "Positivisasi Hukum Islam dalam Pembinaan Hukum Nasional di Indonesia" dalam Al-Ulum (Jurnal Studi Islam) Vol. 13, No. 2, (Desember 2013): pp. 457.

Gray, Christoper Berry (ed). The Philosophy of Law an Encyclopedia. New York and London: Garland Publishing, 1999.

Gurvitch, Georges. Sociology of Law. London: Open University, 1947.

Hermawati, Nety. "Respon Terhadap Hukum Perkawinan di Indonesia", dalam Al-Mizan Vol. 11, No. 1, (Juni 2015): 38-43.

Hidayat, Fatah. "Dinamika Perkembangan Hukum Keluarga di Indonesia, dalam Jurnal An Nisa" Vol. 9, No. 2, (Desember 2014): pp. 1-14.

Ishak, Ajub. "Ciri-ciri Pendekatan Sosiologi dan Sejarah dalam Mengkaji Hukum Islam", dalam Al Mizan Vol. 9, No. 1, (Juni 2013): 71.

Kansil, C.S.T. Pengantar Ilmu Hukum dan Tata Hukum Indonesia. Jakarta: Balai Pustaka, 1989.

Komisi Yudisial Republik Indonesia. Menimbang Ulang Hukum sebagai Saran Rekayasa Sosial. Jakarta: Sekretariat Jenderal Komisi Yudisial Republik Indonesia, 2012.

Rosana, Ellya. "Hukum dan Perkembangan Masyarakat", dalam Jurnal TAPIs Vol. 9, No. 1, (Januari-Juni 2013): 109.

Setiyanto, Danu Aris. Tuhan, Ridhoi Kami: Kajian Perkawinan Beda Agama Pasca Putusan Mahkamah Konstitusi. Surakarta: BukuKu Media, 2016.

Shaham, Ron. "Custom, Islamic Law, and Statutory Legislation: Marriage Registration and Minimum Age at Marriage in the Egyptian Shari'a Courts". dalam Islamic Law and Society, Vol. 2, No. 3, (1995): 258.

Soekanto, Soerjono. Pokok-Pokok Sosiologi Hukum. Jakarta: RajaGrafindo Persada, 2013.

Suherman, Gatot. "Fiqh Mazhab Indonesia Konsep dan Aplikasi Pemikiran Hasbi as-Siddiqi untuk Konteks Islam Rahmat li Indonesia”. dalam Al-Mawarid Vol. XI, No. 1, (Agustus 2010): 112.

Yusdani. Menuju Fiqh Keluaga Progresif. Jakarta: Kaukaba, 2015. 
